\title{
PENERAPAN DIAGRAM KONTROL MEWMA DAN MEWMV PADA PENGENDALIAN KARAKTERISTIK KUALITAS AIR (Studi Kasus: Kualitas Pengolahan Air II PDAM Tirta Moedal Kota Semarang)
}

\author{
Adestya Ayu Maharani ${ }^{1}$, Mustafid $^{2}$, Sudarno. $^{3}$ \\ ${ }^{1,2,3}$ Departemen Statistika, Fakultas Sains dan Matematika, Universitas Diponegoro \\ e-mail : adestyamaharani@gmail.com
}

\begin{abstract}
Water is one of the most important elements for human life, water treatment is done for human consumption and must fulfill the health requirements with the levels of certain parameters. Quality of Water Treatment II is the second water purification installation owned by PDAM Tirta Moedal Semarang City with production capacity of $60 \mathrm{l} / \mathrm{s}$. Variables used in the water treatment process are correlated with each other, so used multivariate control chart. The Multivariate Exponentially Weighted Moving Average control chart is used for monitoring process mean, and the Multivariate Exponentially Weighted Moving Variance control chart is used for monitoring process variability. The variables used are colour, turbidity, organic substance, manganese and the total dissolved solid. MEWMA control chart with $\lambda=0.5$, showed that the process mean is controlled statistically. MEWMV control chart showed that variability is controlled statistically in $\lambda=0.4$, $\omega=0.2$ and $\mathrm{L}=3.3213$. MEWMA and MEWMV control chart showed that the process is not capable because it obtained the value of process capability index less than 1 .
\end{abstract}

Keywords:Water, Multivariate Exponentially Weighted Moving Average, Multivariate Exponentially Weighted Moving Variance, process capability.

\section{PENDAHULUAN}

Air merupakan komponen ekosistem yang sangat penting bagi kehidupan makhluk hidup.Berdasarkan Peraturan Menteri Kesehatan Republik Indonesia Nomor: 492/KEMENKES/PER/IV/2010, air bersih harus memenuhi persyaratan antara lain sebagai berikut: jernih, tidak berwarna, tidak berasa, tidak berbau, tidak beracun, $\mathrm{pH}$ netral dan bebas mikroorganisme. Namun kenyataannya ketersediaan air bersih secara alami sangat terbatas sehingga banyak masyarakat yang tidak mampu memenuhi persyaratan yang ditetapkan oleh Pemerintah.Karena itu diperlukan upaya-upaya untuk mengolah air mentah menjadi air bersih dan mendistribusikannya kepada seluruh masyarakat.

Pengelolaan sumber daya air sangat penting, agar dapat dimanfaatkan secara berkelanjutan dengan tingkat mutu yang diinginkan. Pada PERMENKES Nomor: 492/KEMENKES/PER/IV/2010 telah diatur untuk setiap penyelenggara air minum wajib menjamin air minum yang diproduksinya aman bagi kesehatan.PDAM Tirta Moedal Kota Semarang merupakan perusahaan BUMD Pemerintah Kota Semarang mengelola sumber daya air mejadi air layak konsumsi, dengan memperhatikan kualitas air sebelum didistribusikan kepada pelanggan.

Pada pengendalian kualitas terdapat grafik pengendali, yaitu alat untuk menggambarkan dengan cara yang tepat apa yang dimaksudkan dengan pengendalian statistik, dengan itu dapat digunakan dalam berbagai cara. Grafik pengendali menunjukkan keadaan tak terkendali apabila satu atau beberapa titik jatuh di luar batas pengendali atau apabila titik-titik dalam grafik menunjukkan pola yang tidak random (Montgomery, 2009).

Diagram kontrol multivariat digunakan untuk dua atau lebih karakteristik kualitas, dengan adanya korelasi antar karakteristik kualitas.Diagram konrolMultivariate Weighted Moving Area (MEWMA) merupakan diagram kontrol multivariat yang mengakumulasikan informasi yang didapatkan dari masa lampau, sehinggalebih sensitif untuk mendeteksi pergeseran mean yang lebih kecil. Selain ituDiagram kontrol Multivariate Weighted 
Moving Variance (MEWMV) merupakan diagram kontrol multivariat dengan pengamatan individual untuk mendeteksi perubahan variabilitas proses (Montgomery, 2009).

Tujuan dari penelitian ini adalah menerapkan diagram kontrol MEWMA dan MEWMV dalam mengendalikan karakteristik kualitas air di Kulitas Pengolahan Air II PDAM Tirta Moedal Kota Semarang. Untuk menghitung kemampuan proses dalam memenuhi standar batas-batas spesifikasi kualitas air di Kualitas Pengolahan Air II PDAM Tirta Moedal Kota Semarang.

\section{TINJAUAN PUSTAKA}

Pengendalian kualitas merupakan usaha untuk mempertahankan kualitas dari barang yang dihasilkan, agar sesuai dengan spesifikasi produk yang telah ditetapkan berdasarkan kebijaksanaan pimpinan perusahaan. Tujuan dari pengendalian kualitas yaitubarang hasil produksi dapat mencapai standar kualitas yang telah ditetapkan, biaya inspeksi menjadi sekecil mungkin, biaya desain dari produk dan proses dengan menggunakan mutu produksi tertentu dapat menjadi sekecil mungkin, dan biaya produksi menjadi serendah mungkin (Assauri, 2004). Menurut Ariani (2004), pengendalian kualitas statistik merupakan teknik penyelesaian masalah yang digunakan untuk memonitor, mengendalikan, menganilisis, mengelola dan memperbaiki produk dan proses menggunakan metode metode statistika

Selama tahun 1920-an, konsep pengendalian statistika mutu dikembangkan terutamaa di Laboratorium Bell Telephone oleh Dr. Walter A. Shewart.Shewart memperkenalkan konsep "pengawasan" mutu daripada melakukan inspeksi pada setiap bagian. Untuk keperluan pengawasan mutu, teknik diagram kontrol dari Shewart dikembangkan untuk operasi dalam proses produksi (Masond dan Lind, 1999)

\subsection{Multivariate Exponentially Weighted Moving Average (MEWMA)}

Diagram kendali MEWMA merupakan pengembangan dari peta kendali EWMA yang digunakan untuk mendeteksi terjadinya mean proses yang kecil secara multivariat. Kelebihan diagram kontrol MEWMA adalah robust terhadap asumsi distribusi normal, sehingga ketika data tidak memenuhi asumsi normal maka diagram kendali ini masih bisa digunakan (Montgomery, 2009). Berikut adalah vektor observasi pada diagram kendali MEWMA.

Dimana nilai $0 \leq \lambda \leq 1, \mathrm{j}=1,2, \ldots, n$

$$
\boldsymbol{z}_{j}=\lambda \boldsymbol{x}_{j}+(1-\lambda) \boldsymbol{z}_{\boldsymbol{j}-\mathbf{1}}
$$

$\mathbf{z}_{0}=0$

$\mathbf{x}_{\mathbf{j}}$ : vektor sampel pengamatan ke-j yang berdistribusi normal mujltivariat

$\mathrm{p}$ : banyak variabel yang diamati

$\lambda$ : bobot

Data yang akan diplot pada diagram kontrol adalah sebagai berikut.

$$
T_{j}^{2}=\boldsymbol{z}_{j}^{\prime} \boldsymbol{\Sigma}_{\boldsymbol{Z}_{j}}^{-\mathbf{1}} \mathbf{z}_{\boldsymbol{j}}
$$

dimana matriks varian dan kovarian sebagai berikut,

$$
\Sigma_{Z_{j}}=\frac{\lambda}{2-\lambda}\left[1-(1-\lambda)^{2 j}\right] \Sigma
$$

dengan $\Sigma$ merupakan matriks varian kovarian dari data. Nilai Batas Kendali Atas dalam diagram kontrol MEWMA dinyatakan dalam $\mathrm{H}$. Nilai $\mathrm{H}$ diperoleh berdasarkan nilai pembobot $\lambda$ yang telah ditentukan. Proses dikatakan terkendali apabila nilai pengamatan lebih kecil dari batas kendali atau $\mathrm{T}_{\mathrm{j}}^{2}>\mathrm{H}$. 


\subsection{Multivariate Exponentially Weighted Moving Variance (MEWMV)}

Menurut Huwang et al. (2007) diagram kendali MEWMV digunakan untuk memonitor variabilitas proses tanpa adanya asumsi terjadi perubahan mean proses selama pengendalian berlangsung. MEWMV dibentuk dari persamaan berikut,

$$
\mathbf{V}_{\mathbf{n}}=\omega\left(\boldsymbol{x}_{\mathbf{n}}-\mathbf{z}_{\mathbf{n}}\right)\left(\boldsymbol{x}_{\mathbf{n}}-\mathbf{z}_{\mathbf{n}}\right)^{\prime}+(1-\omega) \mathbf{V}_{\mathbf{n}-\mathbf{1}}
$$

dimana nilai pembobot bernilai $0<\omega<1, \quad 0<\lambda<1$, dan $\mathbf{V}_{\mathbf{0}}=\left(\boldsymbol{x}_{\mathbf{1}}-\mathbf{z}_{\mathbf{1}}\right)\left(\boldsymbol{x}_{\mathbf{1}}-\right.$ $\left.\mathbf{z}_{\mathbf{1}}\right)^{\prime}$.Nilai estimasi dari $\mathrm{z}_{\mathrm{n}}$ dapat dilihat dari persamaan berikut,

$$
\mathbf{z}_{\mathbf{n}}=\lambda \boldsymbol{x}_{\mathbf{n}}+(1-\lambda) \mathbf{z}_{\mathbf{n}-\mathbf{1}}
$$

Dengan $\mathbf{z}_{\mathbf{n}}$ untuk perubahan rata-rata proses pada waktu ke $n$ dapat dilihat pada persamaan berikut (Lowry et al., 1992), dan nilai $\mathrm{z}_{0}=0$.

$$
\mathbf{X}=\left[\begin{array}{c}
x_{1} \\
x_{2} \\
\vdots \\
x_{n}
\end{array}\right] \operatorname{dan} \mathbf{Z}=\left[\begin{array}{c}
z_{1} \\
z_{2} \\
\vdots \\
z_{n}
\end{array}\right]
$$

Untuk mengetahui perubahan dalam matriks kovarians maka harus didefinisikan suatu matriks C.Matriks ini menunjukkan suatu nilai pembobot dari $\mathbf{V}_{\mathbf{n}}$ yang dapat dituliskan:

$$
\mathbf{C}=\left[\begin{array}{ccccc}
(1-\omega)^{n-1} & 0 & 0 & \cdots & 0 \\
0 & \omega(1-\omega)^{n-2} & 0 & \cdots & 0 \\
0 & 0 & \ddots & 0 & 0 \\
\vdots & \vdots & 0 & \omega(1-\omega) & \vdots \\
0 & 0 & \cdots & 0 & \omega
\end{array}\right]
$$

Selanjutnya dilakukan subtitusi persamaan hingga diperoleh hasil sebagai berikut

$$
\mathbf{z}_{\mathbf{n}}=\sum_{j=1}^{n} \lambda(1-\lambda)^{n-j} \boldsymbol{x}_{\mathbf{j}}
$$

$$
\begin{aligned}
\boldsymbol{x}_{\mathbf{n}}-\mathbf{z}_{\boldsymbol{n}}=\boldsymbol{x}_{\boldsymbol{n}}- & \sum_{j=1}^{n} \lambda(1-\lambda)^{n-j} \boldsymbol{x}_{\mathbf{j}} \\
& =(1-\lambda) \boldsymbol{x}_{\boldsymbol{n}}-\lambda(1-\lambda) \boldsymbol{x}_{\mathbf{n}-\mathbf{1}}-\cdots-\lambda(1-\lambda)^{n-1} \boldsymbol{x}_{\mathbf{1}}
\end{aligned}
$$

Kemudian dari persamaan (2.10) dilakukan perhitungan nilai matriks berikut

$$
\begin{aligned}
(\mathbf{X}-\mathbf{Z}) & =\left[\begin{array}{c}
\left(x_{1}-\mathbf{z}_{1}\right) \\
\left(x_{2}-\mathbf{z}_{2}\right) \\
\vdots \\
\left(x_{\mathbf{n}}-\mathbf{z}_{\mathbf{n}}\right)
\end{array}\right] \\
& =\left(\mathbf{I}_{\mathbf{n}}-\mathbf{M}\right) \mathbf{X}
\end{aligned}
$$

dengan $\mathbf{I}_{\mathbf{n}}$ adalah matriks identitas berukuran $\mathbf{n x n}$ dan $\mathbf{M}$ adalah matriks segitiga bawah berukuran nxn dengan $\lambda$ adalah pembobot yang telah ditetapkan.

$$
\mathbf{M}=\left[\begin{array}{cccc}
\lambda & 0 & \cdots & 0 \\
\lambda(1-\lambda) & \lambda & \cdots & 0 \\
\vdots & \vdots & \ddots & \vdots \\
\lambda(1-\lambda)^{n-1} & \cdots & \lambda(1-\lambda) \lambda
\end{array}\right]
$$

berdasarkan persamaan (2.11), maka dapat diperoleh,

$$
\mathbf{V}_{\mathbf{n}}=\mathbf{X}^{\prime} \mathbf{Q X}
$$

Dimana $\mathbf{Q}$ adalah matriks bujur sangkar dengan ukuran nxn

$$
\mathbf{Q}=\left(\mathbf{I}_{\mathbf{n}}-\mathbf{M}\right)^{\prime} \mathbf{C}\left(\mathbf{I}_{\mathbf{n}}-\mathbf{M}\right)
$$

berdasarkan persamaan (2.13) diperoleh, 


$$
\operatorname{tr}\left(\mathbf{V}_{\mathbf{n}}\right)=\operatorname{tr}\left(\mathbf{Q X X} \mathbf{X}^{\prime}\right)
$$

Pada saat $\mathrm{p}=1$ maka persamaan $\operatorname{tr}\left(\mathbf{V}_{\mathbf{n}}\right)$ akan menjadi persamaan EWMV. Saat proses dalam keadaan terkontrol daat ditunjukkan perhitungan untuk mendapatkan $\mathrm{E}\left(\operatorname{tr}\left(\mathbf{V}_{\mathbf{n}}\right)\right)$.

$$
E\left(\operatorname{tr}\left(\boldsymbol{V}_{\boldsymbol{n}}\right)=p \sum_{i=1}^{n} q_{i i}=p \operatorname{tr}(\boldsymbol{Q})\right.
$$

Nilai $E\left[\operatorname{tr}\left(\mathbf{V}_{\mathbf{n}}\right)\right]$ akan konvergen $\operatorname{ke} E\left(\mathbf{V}_{\mathbf{n}}\right)=\frac{2(1-\lambda)^{2} \Sigma}{2-\lambda}$ untuk $\mathrm{n} \rightarrow \infty$ (Huwang, L. et al., 2007), dan perhitungan $\operatorname{Var}\left(\operatorname{tr}\left(\mathbf{V}_{\mathbf{n}}\right)\right)$ sebagai berikut.

$$
\operatorname{Var}\left(\operatorname{tr}\left(\boldsymbol{V}_{\boldsymbol{n}}\right)=2 p \sum_{i=1}^{n} \sum_{j=1}^{n} q_{i j}^{2}\right.
$$

Persamaan (2.17) akan menjadi batas yang memungkinkan untuk setiap n. berdasarkan persamaan (2.16) pula didapatkan batas diagram kontrol berdasarkan $\operatorname{tr}\left(\mathbf{V}_{\mathbf{n}}\right)$ yaitu

$$
\mathrm{E}\left[\operatorname{tr}\left(\mathbf{V}_{\mathbf{n}}\right)\right] \pm \mathrm{L} \sqrt{\operatorname{Var}\left[\operatorname{tr}\left(\mathbf{V}_{\mathbf{n}}\right)\right]}=\mathrm{p} \operatorname{tr}(\mathbf{Q}) \pm \mathrm{L} \sqrt{2 \mathrm{p} \sum_{\mathrm{i}=1}^{\mathrm{n}} \sum_{\mathrm{j}=1}^{\mathrm{n}} \mathrm{q}_{\mathrm{ij}}^{2}}
$$

dimana L merupakan konstanta yang bergantung pada nilai $\omega$ (smoothing constant) dan $\lambda$ yang telah ditentukan sebelumnya.

\section{A. Distribusi Normal Multivariat}

Salah satu asumsi yang harus dipenuhi untuk melakukan pengendalian kualitas menggunakan diagram kendali multivariat adalah data berdistribusi normal multivariat.Adapun prosedur dalam pengujian distribusi normal multivariat yang akana dilakukan, yaitu dengan membuat $q-q$ plot dengan tahapan pertama menentukan nilai vektor rata-rata dan matriks varian kovarian. Kemudian menentukan nilai jarak Mahalanobis setiap titik pengamatan dengan vektor rata-ratanya dengan persamaan $d_{j}^{2}=$ $\left(\boldsymbol{x}_{\boldsymbol{j}}-\overline{\boldsymbol{x}}\right)^{\prime} \boldsymbol{S}^{-1}\left(\boldsymbol{x}_{\boldsymbol{j}}-\overline{\boldsymbol{x}}\right)$. Setelah nilai $d_{j}^{2}$ diperoleh, urutkan nilai $d_{j}^{2}$ dari kecil ke besar. Menentukan nilai $q_{j}$ dengan persamaan berikut,

$$
q_{j, p}\left(p_{j}\right)=X_{p}^{2}\left(\left(n-j+\frac{1}{2}\right) / n\right)
$$

dimana nilai $p_{j}=\frac{j-1 / 2}{n}, j=1,2, \ldots, n$

Selanjutnya buat scatterplot $d_{j}^{2}$ dengan $q_{j}$.Jika scatterplot ini cenderung membentuk garis lurus dan sekitar $50 \%$ nilai $d_{j}^{2} \leq \chi_{p, 0.50}^{2}$ maka dapat dikatakan bahwa data berdistribusi normal multivariat.

\section{B. Uji Dependensi Variabel}

Variabel $x_{1}, x_{2}, \ldots, x_{p}$ dikatakan saling bebas jika matriks korelasi antar variabel membentuk matriks identitas (Morrison, 1990).

Hipotesis

$\mathrm{H}_{0}: \mathbf{R}=\mathbf{I}$ (tidak ada korelasi antar variabel)

$\mathrm{H}_{1}: \mathbf{R} \neq \mathbf{I}$ (ada korelasi antar variabel)

Statistik Uji:

$$
X_{\text {hitung }}^{2}=-\left\{n-1-\frac{2 p+5}{6}\right\} \ln |\boldsymbol{R}|
$$

Sehingga keputusan menerima $\mathrm{H}_{0}$ yang berarti antar variabel bersifat saling bebas, jika nilai $X_{\text {hitung }}^{2} \leq X_{\left(\alpha, \frac{1}{2} p(p-1)\right)}^{2}$. Dengan n merupakan banyaknya observasi, $\mathrm{p}$ adalah banyaknya karakteristik, dan $\boldsymbol{R}$ adalah matriks korelasi dari masing-masing variabel. 


\subsection{Analisis Kapabilitas Proses}

Kapabilitas proses merupakan suatu pengukuran yang digunakan untuk mengevaluasi keseluruhan proses.Multivariate Proses Capability Indices (MPCI) menunjukkan seberapa baik sebuah proses manufaktur dapat menemui batas spesifikasi ketika karakteristik kualitas memiliki korelasi. Suatu proses produksi berjalan secara capable apabila nilai $\mathrm{C}_{\mathrm{pm}} \geq 1$. Perhitungan indeks $\mathrm{C}_{\mathrm{pm}}$ dan $\mathrm{C}_{\mathrm{pmk}}$ untuk data univariat adalah:

$$
\begin{gathered}
\mathrm{C}_{\mathrm{pm}}\left(X_{i}\right)=\frac{\mathrm{USL}_{X_{i}}-\mathrm{LSL}_{X_{i}}}{\sqrt[6]{\sigma_{X_{i}}^{2}+\left(\mu_{X_{i}}-T_{X_{i}}\right)^{2}}} \\
\mathrm{C}_{\mathrm{pmk}}\left(X_{i}\right)=\min \left\{\frac{\mathrm{USL}_{X_{i}}-\widehat{\mu}_{X_{i}}}{\sqrt[3]{\sigma_{X_{i}}^{2}+\left(\mu_{X_{i}}-T_{X_{i}}\right)^{2}}}, \frac{\widehat{\mu}_{X_{i}}-\mathrm{LSL}_{X_{i}}}{\sqrt[3]{\sigma_{X_{i}}^{2}+\left(\mu_{X_{i}}-T_{X_{i}}\right)^{2}}}\right\}
\end{gathered}
$$

Keterangan :

USL = batas spesifikasi atas

LSL = batas spesifikasi bawah

Sehubungan dengan adanya lima karakteristik kualitas yang digunakan dalam penelitian ini merupakan kasus multivariat, maka perhitungan indeks kapabilitasnya adalah,

$$
\begin{aligned}
& M C_{p m}=\sum_{i=1}^{p} W_{i} C_{p m}\left(X_{i}\right) \\
& M C_{p m k}=\sum_{i=1}^{p} W_{i} C_{p m k}\left(X_{i}\right)
\end{aligned}
$$

Dimana $\mathrm{MC}_{\mathrm{PM}}, \mathrm{MC}_{\mathrm{PMK}}$ berturut-turut merupakan $\mathrm{C}_{\mathrm{PM}}, \mathrm{C}_{\mathrm{PMK}}$ multivariat dengan $\mathrm{W}_{\mathrm{i}}$ merupakan pembobot berdasarkan kepentingan dengan $\sum_{i=1}^{p} W_{i}=1$ (Raissi, 2009).

\section{METODE PENELITIAN}

Data yang digunakan dalam penelitian ini merupakan data sekunder yang diperoleh dari PDAM Tirta Moedal Kota Semarang. Sampel yang digunakan merupakan parameter kualitas air berupa warna, kekeruhan, jumlah zat padat terlarut, zat organik dan mangandi Instalasi Pengolahan Air II PDAM Tirta Moedal Kota Semarang yang diambil setiap minggu mulai periode Februari 2017 hingga Februari 2018.

Sesuai dengan tujuan penelitian ini untuk menerapkan diagram kontrol MEWMA dan MEWMV dalam mengendalikan karakteristik kualitas air di Kulitas Pengolahan Air II PDAM Tirta Moedal Kota Semarang, data harus berdistribusi normal multivariat dan saling berkorelasi. Karena asumsi tersebut merupakan syarat agar data dapat dioleh menggunakan diagram kontrol. Selain itu sebelum membuat diagram kontrol MEWMA dan MEWMV, dilakukan standarisasi data sesuai dengan $z$-score karena data memiliki skala pengukuran yang berbeda-beda. Jika titik-titik pengamatan dalam diagram kendali MEWMA dan MEWMV terkendali atau berada di dalam batas kendali atas dan bawah, maka dapat menghitung indeks kemampuan proses. Indeks kemampuan proses menunjukkan seberapa baik kualitas air di Kualitas Pengolahan Air II PDAM Tirta Moedal Kota Semarangmemenuhi standar batas-batas spesifikasinya.

\section{HASIL DAN PEMBAHASAN}

\subsection{Deskripsi Data}

Deskripsi karakteristik air yang sudah melewati proses klorinasi dapat dilihat pada Tabel 1. Proses pengendalian menggunakan data mingguan bulan Februari 2017 sampai Februari 2018 sebanyak 51 pengamatan dengan 5 variabel karakteristik kualitas air. 
Tabel 1. Deskripsi Karakteristik Kualitas

\begin{tabular}{lccccc}
\hline \multicolumn{1}{c}{ Variabel } & Mean & Varian & St. Dev & Minimum & Maksimum \\
\hline Warna & 5,88235 & 11,2659 & 3,3565 & 0 & 11 \\
Kekeruhan & 0,88 & 0,1085 & 0,3294 & 0,35 & 1,67 \\
Zat Organik & 7,233 & 2,1926 & 1,481 & 3,16 & 9,84 \\
Mangan & 0,02194 & 0,00014 & 0,0119 & 0 & 0,062 \\
TDS & 146,647 & 553,753 & 23,532 & 106 & 210 \\
\hline
\end{tabular}

\subsection{Asumsi Normalitas}

Salah satu asumsi yang harus dipenuhi untuk melakukan pengendalian kualitas menggunakan diagram kontrol multivariat dan analisis kapabilitas adalah data berdistribusi normal multivariat.Dengan menghitung nilai $\mathrm{d}_{\mathrm{j}}{ }^{2}$ dengan persamaan $d_{j}^{2}=\left(\boldsymbol{x}_{\boldsymbol{j}}-\right.$ $\overline{\boldsymbol{x}})^{\prime} \boldsymbol{S}^{-1}\left(\boldsymbol{x}_{\boldsymbol{j}}-\overline{\boldsymbol{x}}\right)$, kemudian dibandingkan dengan $\chi_{5,0.50}^{2}=4,351$, diperoleh tabel sebagai berikut,

Tabel 2. Hasil perhitungan nilai $\mathrm{d}_{\mathrm{j}}^{2}$

\begin{tabular}{cccc}
\hline $\mathrm{j}$ & $\mathrm{d}_{\mathrm{j}}{ }^{2}$ & $\chi_{5,0.50}^{2}$ & Keterangan \\
\hline 1 & 3,364 & 4,351 & lebih kecil \\
\hline 2 & 2,709 & 4,351 & lebih kecil \\
\hline 3 & 5,064 & 4,351 & lebih besar \\
\hline 4 & 9,585 & 4,351 & lebih besar \\
\hline 5 & 1,730 & 4,351 & lebih kecil \\
\hline 6 & 1,132 & 4,351 & lebih kecil \\
\hline 7 & 6,260 & 4,351 & lebih besar \\
\hline 8 & 2,878 & 4,351 & lebih kecil \\
\hline 9 & 11,333 & 4,351 & lebih besar \\
\hline$\vdots$ & $\vdots$ & $\vdots$ & $\vdots$ \\
\hline 51 & 5,844 & 4,351 & lebih besar \\
\hline
\end{tabular}

Berdasarkan Tabel 2, dari 51 pengamatan lebih dari 50\% nilai $\mathrm{d}_{\mathrm{j}}^{2}$ lebih kecil dari nilai $\chi_{5,0.50}^{2}=4,351$. Maka dapat diasumsikan data karakteristik kualitas air berdistribusi normal.

\subsection{Uji Dependensi Variabel}

Data yang digunakan merupakan data multivariat sehingga perlu dilakukan adanya uji korelasi antar variabel.Untuk mengetahui kelima variabel tersebut berhubungan perlu dilakukan uji dependensi variabel menggunakan uji Bartlett. Hipotesis:

$$
\begin{array}{ll}
H_{0} & : \mathbf{R}=\mathbf{I} \text { (tidak ada korelasi antar variabel) } \\
H_{1} & : \mathbf{R} \neq \mathbf{I} \text { (ada korelasi antar variabel) }
\end{array}
$$

Statistik Uji:

$$
x_{\text {hitung }}^{2}=-\left\{n-1-\frac{2 p+5}{6}\right\} \ln |\boldsymbol{R}|
$$




$$
\begin{aligned}
& x_{\text {hitung }}^{2}=26,55212 \\
& p-\text { value }=0,00307
\end{aligned}
$$

Pada taraf signifikansi $\alpha=5 \% H_{0}$ ditolak, karena nilai $X_{\text {hitung }}^{2}$ sebesar 26,55212> $\chi_{(0,05,10)}^{2}$ sebesar 18,31 dan p-value bernilai $0,00307<\alpha$ sebesar 0,05.. Dapat disimpulkan kelima variabel pada karakteristik kualitas air terdapat korelasi.

\subsection{Pengendalian Kualitas pada Mean Proses Pengolahan Air}

Pengendalian rata-rata proses dilakukan dengan menggunakan diagram kontrolMultivariate Exponentially Weighted Moving Average (MEWMA).Pada diagram kontrol ini digunakan nilai pembobot $\lambda$ sebesar 0,5. Menurut Montgomery (2009), semakin kecil lamda akan lebih efektif dalam mendeteksi pergeseran mean proses yang kecil. Semakin besar nilai lamdanya, semakin besar juga lebar batas pengendali diagram kontrol.

Penerapan diagram kontrol MEWMA menggunakan software Microsoft Excel. Sebelum dilakukan perhitungan, terlebih dahulu data menstandarkan data sesuai dengan $z$ score. Dengan nilai awal $\mathrm{Z}_{0}=0$ dan $\lambda=0.5$, serta banyaknya pengamatan yang dilakukan adalah 51 , dapat dilakukan perhitungan $Z_{j}$ dengan persamaan (2.3). Setelah nilai $Z_{j}$ diperoleh, dilakukan perhitungan untuk titik yang akan diplotkan dalam diagram kontrol MEWMA dengan persamaan (2.4).Sehingga diperoleh nilai $T_{j}^{2}$ terkecil adalah 1,56438 pada pengamatan ke-20, dan nilai $T_{j}^{2}$ terbesar adalah 17,55166 pada pengamatan ke-11.

Pada diagram kontrol MEWMA dengan jumlah pengamatan sebanyak 51, nilai pembobot $\lambda$ sebesar 0,5 , dan jumlah variabel karakteristik kualitas air yang diamati ada 5, dapat diperoleh nilai Batas Kendali Atas sebesar 18,09 dan Batas Kendali Bawah 0.

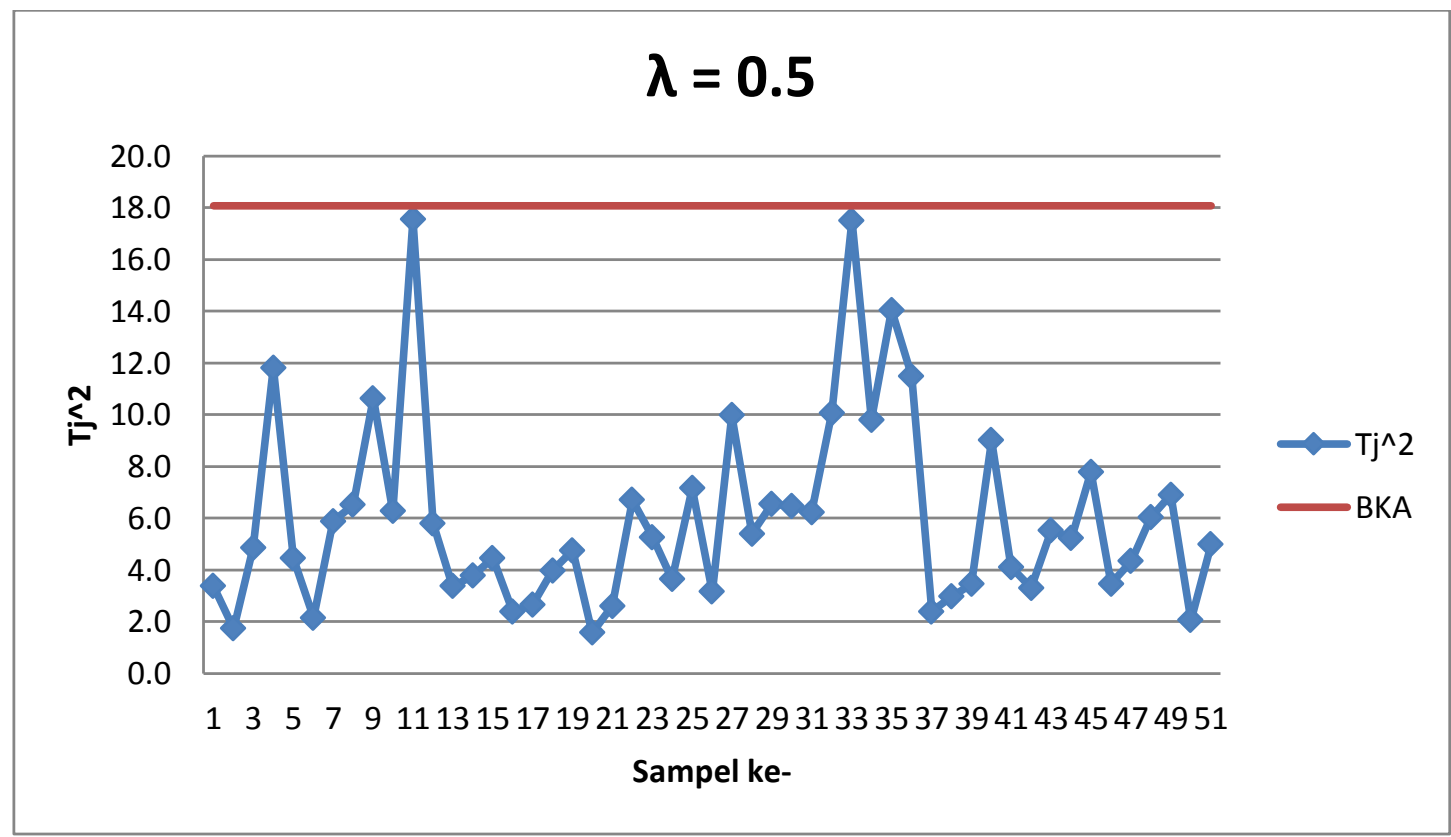

Gambar 1. Diagram Kontrol MEWMA dengan $\lambda=0,5$

Berdasarkan Gambar 1, semua pengamatan sebanyak 51 pengamatan berada pada kondisi in-control karena tidak ada titik yang berada di luar batas kendali. Maka dapat diasumsikan bahwa proses mean terkendali secara statistik.

\section{5. $\quad$ Pengendalian Kualitas pada Variabilitas Proses Pengolahan Air}

Pengendalian kualitas pada variabilitas proses dilakukan dengan menggunakan peta kendali peta kendali Multivariate Exponentially Weighted Moving Variance (MEWMV). 
Penelitian ini menggunakan pembobot $\omega=0,2$ dan $\lambda=0,4$. Menurut Huwang (2007) nilai pembobot $\omega$ dan $\lambda$ masing-masing kurang dari sama dengan 0,4 memberikan kinerja yang lebih baik untuk memonitoring variabilitas proses.

Penerapandiagram kontrol MEWMV menggunakan software MATLAB. Untuk memperoleh nilai $\operatorname{tr}\left(\mathrm{V}_{\mathrm{n}}\right)$ atau titik yang akan diplotkan pada diagram kontrol MEWMV, diperlukan matriks $\mathrm{C}$ untuk mengetahui perubahan dalam matriks kovarian dengan persamaan (2.9), matriks $M$ berupa matrik segitiga bawah dengan elemen $\lambda$ pada persamaan (2.12) dan matriks Q yang diperoleh dari persamaan (2.14). Setelah dilakukan berbagai langkah dapat diperoleh titik-titik yang akan diplotkan dalam diagram kontrol MEWMV dengan persamaan (2.15). Sehingga diperoleh nilai $\operatorname{tr}\left(\mathrm{V}_{\mathrm{n}}\right)$ terkecil adalah 0,9561 pada pengamatan ke-2, dan nilai $\operatorname{tr}\left(\mathrm{V}_{\mathrm{n}}\right)$ terbesar adalah 3,1093 pada pengamatan ke-11.

Pada diagram kontrol MEWMV dengan menggunakan pembobot $\omega=0,2$ dan $\lambda=$ 0,4 sehingga diperoleh nilai konstanta $\mathrm{L}=3,3213$. Selanjutnya memplotkan titik pengamatan dengan batas kendali atas dan batas kendali bawah dengan persamaan (2.18) untuk setiap pengamatannya.

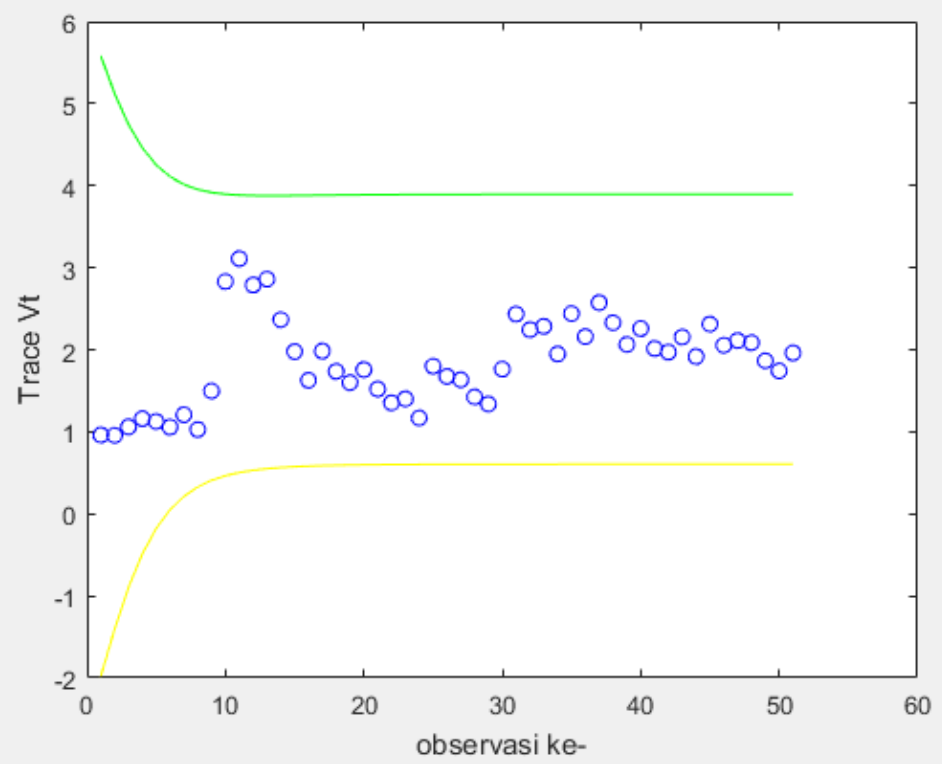

Gambar 2. Diagram Kontrol MEWMV dengan $\omega=0,2$ dan $\lambda=0,4$

Berdasarkan Gambar 2, sebanyak 51 plot $\operatorname{tr}\left(\mathbf{V}_{\mathbf{n}}\right)$ berada di dalam batas kendali atas maupun batas kendali bawah. Sehingga dapat disimpulkan bahwa variabilitas proses terkendali secara statistika.

\subsection{Analisis Kapabilitas Proses Kualitas Air Produksi}

Analisis kapabilitas proses pada penelitian ini berguna untuk mengetahui secara keseluruhan kinerja dari proses yang dilakukan dalam pengolahan air PDAM Tirta Moedal Kota Semarang. Indeks yang digunakan untuk mengukur kapabilitas proses dalam penelitian adalah $\mathrm{C}_{\mathrm{pm}}$ dan $\mathrm{C}_{\mathrm{pmk}}$ ketika data pengamatan telah terkendali secara statistik. Suatu proses dikatakan baik apabila nilai indeks yang dihasilkan lebih dari 1 .

Batas spesifikasi yang digunakan oleh PDAM Tirta Moedal untuk setiap karakteristik kualitasnya diambil berdasarkan Permenkes No 492 Tahun 2010.Berikut batas spesifikasi bawah dan batas spesifikasi atas untuk setiap karakteristik kualitas warna, kekeruhan, zat organik, mangan dan TDS dapat dilihat pada Tabel 3. 
Tabel 3. Batas Spesifikasi Karakteristik Kualitas

\begin{tabular}{lcc}
\hline Variabel & $\begin{array}{c}\text { Batas } \\
\text { Spesifikasi } \\
\text { Bawah }\end{array}$ & $\begin{array}{c}\text { Batas } \\
\text { Spesifikasi } \\
\text { Atas }\end{array}$ \\
\hline Warna & 0 & 50 \\
Kekeruhan & 0 & 5 \\
Zat Organik & 0 & 10 \\
Mangan & 0 & 0,4 \\
TDS & 0 & 500 \\
\hline
\end{tabular}

\section{A. Analisis Kapabilitas Proses Diagram Kontrol MEWMA}

Untuk mendapatkan nilai indeks $\mathrm{MC}_{\mathrm{pm}}$ dan $\mathrm{MC}_{\mathrm{pmk}}$ diperlukan nilai indeks $\mathrm{C}_{\mathrm{pm}}$ dan $\mathrm{C}_{\text {pmk. }}$. Sesuai dengan persamaan (2.19) dan (2.20) diperoleh nilai indeks kapabilitas proses secara univariat atau indeks $\mathrm{C}_{\mathrm{pm}}$ dan $\mathrm{C}_{\mathrm{pmk}}$, dengan nilai USL dan LSL ditentukan berdasarkan spesifikasi target atas dan bawah dari Permenkes yang telah distandarkan, disesuaikan dengan z-score.

Setelah dilakukan analisis kapabilitas secara univariat dilakukan perhitungan nilai $\mathrm{MC}_{\mathrm{pm}}$ dan $\mathrm{MC}_{\mathrm{pmk}}$ dengan nilai indeks $\mathrm{C}_{\mathrm{pm}}$ dan $\mathrm{C}_{\mathrm{pmk}}$ yang telah didapatkan menggunakan persamaan (2.21) dan (2.22). diperoleh nilai $\mathrm{MC}_{\mathrm{pm}}$ sebesar 0,5304 dan $\mathrm{MC}_{\mathrm{pmk}}$ sebesar 0,2184. Kedua nilai indeks kapabilitas proses multivariat lebih kecil dari 1 yang menandakan bahwa secara multivariat kinerja proses memiliki presisi yang kurang baik pada kelima variabel tersebut. Jadi, dapat disimpulkan bahwa kapabilitas prosespengolahan air PDAM Tirta Moedal Kota Semarang menggunakan diagram kontrol Multivariate Exponentially Weighted Moving Average tidak capable, karenakan proses cenderung mendekati batas spesifikasi bawah.

\section{B. Analisis Kapabilitas Proses Diagram Kontrol MEWMV}

Untuk mendapatkan nilai indeks $\mathrm{MC}_{\mathrm{pm}}$ dan $\mathrm{MC}_{\mathrm{pmk}}$ diperlukan nilai indeks $\mathrm{C}_{\mathrm{pm}}$ dan $\mathrm{C}_{\mathrm{pmk}}$. Sesuai dengan persamaan (2.19) dan (2.20) diperoleh nilai indeks kapabilitas proses secara univariat atau indeks $\mathrm{C}_{\mathrm{pm}}$ dan $\mathrm{C}_{\mathrm{pmk}}$, dengan menggunakan data yang sudah terboboti yaitu $\mathrm{V}_{\text {npersamaan }}$ (2.6).

Setelah dilakukan analisis kapabilitas secara univariat dilakukan perhitungan nilai $\mathrm{MC}_{\mathrm{pm}}$ dan $\mathrm{MC}_{\mathrm{pmk}}$ dengan nilai indeks $\mathrm{C}_{\mathrm{pm}}$ dan $\mathrm{C}_{\mathrm{pmk}}$ yang telah didapatkan menggunakan persamaan (2.21) dan (2.22).diperoleh nilai $\mathrm{MC}_{\mathrm{pm}}$ sebesar 0,5771 dan $\mathrm{MC}_{\mathrm{pmk}}$ sebesar 0,2451. Kedua nilai indeks kapabilitas proses multivariat lebih kecil dari 1 yang menandakan bahwa secara multivariat kinerja proses memiliki presisi yang kurang baik pada kelima variabel tersebut. Jadi, dapat disimpulkan bahwa kapabilitas prosespengolahan air PDAM Tirta Moedal Kota Semarang menggunakan diagram kontrol Multivariate Exponentially Weighted Moving Variance tidak capable, karenakan proses cenderung mendekati batas spesifikasi bawah. 


\section{KESIMPULAN}

Data karakteristik kualitas proses produksi air di Kualitas Pengolahan Air II PDAM Tirta Moedal Kota Semarang pada periode bulan Februari 2017 hingga Februari 2018 dilakukan penerapan diagram kontrol Multivariate Exponentially Weighted Moving Average (MEWMA) menunjukkan bahwa mean proses terkendali secara statistik dengan $\lambda$ $=0,5$. Sedangkan penerapan diagram kontrol Multivariate Exponentially Weighted Moving Variance (MEWMV) menunjukkan bahwa variabilitas proses terkendali secara statistik dengan pembobotan $\omega=0,2$ dan $\lambda=0,4$. Nilai kapabilitas proses multivariat untuk masingmasing diagram kontrol MEWMA dan MEWMV kurang dari 1, sehingga menunjukkan proses multivariat pada pengolahan air di Kualitas Pengolahan Air II PDAM Tirta Moedal Kota Semarang tidak kapabel. Karena kinerja proses memiliki presisi yang kurang baik pada kelima variabel tersebut, dimana proses cenderung medekati batas spesifikasi bawah. Namun dalam praktiknya, proses dianggap berjalan dengan baik. Karena jika proses semakin mendekati batas spesifikasi atas, mengindikasikan kualitas air yang tidak lebih baik dibandingkan dengan kualitas air yang mendekati batas spesifikasi bawah dengan variabel yang telah diamati.

\section{DAFTAR PUSTAKA}

Ariani, D.W. 2004.Pengendalian Kualitas Statistik (Pendekatan Kuantitatif Dalam Manajemen Kualitas). Yogyakarta : ANDI.

Assauri, S. 2004. Manajemen Produksi dan Operasi.Jakarta : Lembaga Penerbit Fakultas Ekonomi Universitas Indonesia

Huwang, L., Arthur, \& Chien-Wei. (2007). Monitoring Multivariate Process Variability for Individual Observations. Journal of Quality Technology, 39.pp .258-278.

Johnson, R.A. dan Wichern, D.W. 2007.Applied Multivariate Statistical Analysis Sixth Edition. United States of America: Pearson Education.

Lowry, C.A et al. 1992. A Multivariate Exponentially Weighted Moving Average Control Chart. Technometrics Vol. 34, No. 1: Hal. 46 - 53

Masond, R.D and Lind, D.A. 1999. Teknik Statistika Untuk Bisnis \& Ekonomi Edisi ke-9 jilid dua. Alih bahasa : Wikarya Uka, Soetjipto Widyono \& Sugiharso. Erlangga, Jakarta. Terjemahan dari: Statistical Technique in Business and Economics.

Montgomery, D.C. 2009. Statistical Quality Control, Sixth Edition Singapore: John Wiley \& Sons.

Morrison, D. 1990. Multivariate Statistical Methods (Third Edition). New York: Mc Graw Hill Publishing Company.

Raissi, S. 2009. Multivariate Process Capability Indices On The Presence Of Priority For Quality Characteristics. Journal of Industrial Engineering, Vol. 5, No.9: Hal. 27-36 